\section{Dr. PAULSTEPHANECK Primeiro Professor Emérito da FFFCL RP - USP}

Ao aprovar a atribuição do título de Professor Emérito da Faculdade de Filosofia, Ciências e Letras de Ribeirão Preto ao Dr. Paul Stephaneck, a Congregação desta Unidade da USP baseou-se nos fatos que evidenciam as fortes bases que sustentam no presente o Departamento de Psicologia e Educação, que permitem desenhar um futuro ainda mais promissor; trata-se de um professor que aqui plantou idéias e ideais que cuidados com a dedicação do tempo integral, cresceram e frutificaram, formando um conjunto muito grande de estudantes e trazendo a implantação e desenvolvimento de diversas áreas do conhecimento da Psicologia no Brasil, além de permitir que a interdisciplinaridade se instalasse no programa de graduação e depois no de pós-graduação.

Vindo da Bélgica em 1966, o professor aqui trabalhou por 25 anos, até se aposentar, sempre fundamentado em Princípios Científicos, Éticos e na Exigência de que o Estudo fosse assumido com Seriedade e Constância. Este mestre, nascido na Hungria, cursou Humanités no Gymnasium d'État à Budapest, iniciou a graduação na sua terra natal, depois foi para a Bélgica e em 1962 obteve a Licencie em Sciences Psychologiques na Université Libre de Bruxelles, onde sempre teve um alto nível de desempenho, concluindo seus estudos com o mémoire 'L'influence de l'environnement sur la créativité chez les dessinateurs industriels. Logo após obter seu diploma de graduação tornou-se membro da Societé d'Ergonomie de Langue Française e da Société Belge de Psychologie, começando a participar de eventos, apresentando trabalhos, publicando resumos e artigos científicos.

Decorrido algum tempo, tomou ciência do convite do professor Lucien Lison, e decidiu aceitar a proposta, vindo, em meados da década de 60 , "aportar", junto com sua esposa, a professora Paula Ottilia Stephaneck-Benedek, na recém instalada Faculdade de Filosofia, Ciências e Letras de Ribeirão Preto.

É seu o texto 'Turbulências na decolagem' em que relata as dificuldades enfrentadas para sair da
Bélgica e chegar ao Brasil; e, o que para outros poderia ter sido motivo para desistir ou colocar empecilhos, para ele ficou apenas como uma história a ser partilhada.

Ao chegar, avaliou o que tinha sido ensinado às primeiras turmas de Psicologia até aquele momento, viu tudo o que faltava para que a formação mantivesse a característica de preparo para a pesquisa científica, fosse diversificada e incluísse o conhecimento das áreas que vinham sendo trabalhadas mais recentemente; daí planejou e, sem medir esforços, ministrou as disciplinas que julgou serem necessárias para garantir que todas as oportunidades de aprendizagem fossem dadas aos estudantes. Então, veio e distribuiu 'a mãos cheias' o seu saber, construído na seriedade do estudo, no interesse pela pesquisa, e mantendo o contato com professores de Universidades européias, continuou produzindo e partilhando.

Tinha, pois, inteira razão o professor Lucien Lison quando, ao solicitar ao governo do Estado o contrato do professor Paul Stephaneck como Regente, afirmou que a sua vinda para a Faculdade de Filosofia aumentaria, de maneira considerável, o potencial científico e didático desta Unidade, além de que estaria implantando uma linha de trabalho até então ausente no Brasil - a da Psicologia Industrial, pois sua área de investigação a Ergonomia, Ciência que trata da adaptação das técnicas e dos ambientes ao trabalho humano, era, até aquele momento, desconhecida.

Sim, foram várias as linhas de pesquisa que o professor Paul Stephaneck desenvolveu que merecem destaque: Problemas da Psicologia Industrial, Pesquisa Operacional, Avaliação da Carga de Trabalho. Além disso, criou um forum de discussão sobre os Diferentes Modelos de pesquisa na área das Ciências Humanas. E, importante assinalar: seu Curriculum evidencia regularidade de produção científica.

Também, ele manteve ao longo dos anos a preocupação com trazer para os estudantes e demais docentes do Depto tudo o que estivesse sendo publicado no exterior na sua área, e nas que, pela sua sábia avaliação, pudessem interessar ou ser fonte de novas idéias, disciplinas e pesquisas, continuando com seus contatos nas Universidades Estrangeiras, incluin- 


\section{8}

do o Max-Planck Institut, o que permitiu, a quem dele se aproximou, uma orientação segura, atualizada e voltada para a diversidade.

Aos alunos da graduação em Psicologia, para além de acolhê-los sempre, abriu um conjunto grande de possibilidades ao lecionar matérias inteiramente novas. E muitas outras foram as linhas de atuação deste professor, sendo chefe do Departamento de 1977 a 1992, por 21 vezes.

Essa volta ao passado torna cada vez mais claro que se está diante de uma pessoa que, de acordo com o professor Kreppner - pesquisador do Max Planck Institut - é um SÁBIO, porque acumulou, estruturou, além de ter o cuidado de difundir, um conjunto amplo e diversificado de conhecimentos.E, sempre fez isto mantendo uma atitude de extrema simpatia, respeitando as diferenças, buscando recursos para explicar e explicar e explicar, criando condições para que pudesse acontecer a prática, muito provavelmente por acreditar que 'fazendo, refazendo e analisando' a aprendizagem se concretiza.

Portanto, atribuir ao professor Paul Stephaneck o título de Emérito é além de um ato de justiça, um dever. Ele merece e muito que se possa mostrar às gerações mais novas que tivemos um Professor de enorme valia. 